\title{
PENGARUH IN STORE DISPLAY TERHADAP KEPUTUSAN PEMBELIAN MINUMAN BERKARBONASI COCA-COLA \\ (Survei pada Konsumen di Carrefour Paris Van Java Sukajadi Bandung)
}

\author{
Rozmita Dewi Yuniarti \\ Ridwan Subhi Aprianti
}

\begin{abstract}
Abstrak
Industri minuman berkarbonasi yang saat ini masih dikuasai oleh Coca-Cola Company dengan perolehan pangsa pasar paling tinggi dibanding dengan pesaingnya pepsi cola maupun Multi Bintang Indonesia yang meluncurkan produk Green Sands. Akan tetapi meskipun pangsa pasar minuman berkarbonasi dikuasai Coca-Cola Company saat ini terjadi persaingan antar sesama produk Coca-Cola bahkan pada tahun 2006 Brand Share minuman berkarbonasi dikuasai oleh merek Fanta 33,7\%, merek Coca-Cola sebesar 28,5\%, merek Sprite sebesar 30,9\%, Pepsi Cola sebesar 0,9\%. Salah satu keberhasilan Fanta dalam menggeser Coca-Cola adalah strategi yang diterapkan Fanta yaitu diferensiasi dan target sasarannya adalah anak remaja, diferensiasi Fanta adalah dari rasa. Untuk itu Coca-cola sebagai merek minuman berkarbonasi paling tua terus melakukan strategi in store display yang belum di masuki pesaing sejenis. Tujuan penelitian ini ialah untuk mengetahui gambaran in store display dan keputusan pembelian Coca-Cola di Carrefour Paris Van Java, serta Menjelaskan seberapa besar pengaruh in store display terhadap keputusan pembelian Coca-Cola di Carrefour Paris Van Java.

Berdasarkan variabel yang diteliti maka jenis penelitian ini adalah penelitian deskriptif dan verifikatif. Jangka waktu penelitian bersifat cross sectional method. Populasi penelitian ini berjumlah 1.291 orang konsumen Coca-Cola di Carrefour Paris Van Java JI Sukajadi Bandung, yang merupakan rata-rata konsumen perbulan. Berdasarkan teknik penarikan sampel secara systematic random sampling dan dengan menggunakan rumus Slovin diperoleh sampel sebesar 93 sampel, namun untuk meningkatkan keakuratan maka jumlah sampel yang diteliti ditambah sehingga berjumlah 100 sampel. Data yang digunakan adalah data primer dan sekunder dengan teknik pengumpulan data melalui wawancara, observasi, penyebaran kuesioner dan studi literatur. Analisis data dan uji hipotesis menggunakan analisis jalur (path analysis) dengan bantuan software komputer SPSS 15, teknik analisis jalur ini digunakan untuk mengetahui pengaruh langsung maupun tidak langsung dari setiap variabel bebas terhadap variabel terikat.

Hasil penelitian menunjukkan bahwa pelaksanaan in store display secara umum sudah baik dengan indikator branding dalam kemudahan mengenali merek Coca-Cola pada rak pajangan (display) merupakan dimensi yang paling tinggi mendapatkan skor, sedangkan perolehan hasil skor paling rendah diperoleh indikator modularity ditinjau dari segi kesesuaian rak pajangan dengan merek Coca-Cola yang baru. Keputusan pembelian yang terdiri dari pemilihan produk, pemilihan merek, pemilihan saluran pembelian, waktu pembelian, dan jumlah pembelia secara umum sudah baik dengan indikator kepercayaan terhadap merek memperoleh skor yang paling tinggi, sedangkan pemilihan berdasarkan waktu pembelian ditinjau dari ketidakteraturan pembelian mendapatkan skor yang paling rendah. In store display berpengaruh secara positif terhadap keputusan pembelian, sehingga setiap kegiatan promosi yang dibentuk dengan perencanaan yang baik dalam pelaksanaan in store display akan mempengaruhi keputusan pembelian.
\end{abstract}

Kata Kunci: In Store Display dan Keputusan Pembelian

\section{PENDAHULUAN}

Perkembangan era globalisasi dunia bisnis berkembang cukup signifikan dan mereka terus bersaing untuk menguasai pasar. Era globalisasi ini juga ditunjang dengan semakin pesatnya perkembangan teknologi informasi dan komunikasi sehingga masyarakat di seluruh dunia bisa terhubung dengan masyarakat dibelahan dunia lain tanpa adanya hambatan, hal ini juga disebut dengan istilah "dunia tanpa batas". Begitu juga persaingan dalam dunia bisnis dengan memanfaatkan globalisasi serta kemajuan teknoligi 


\section{StrategiC}

informasi dan komunikasi mereka dapat dengan mudah memasuki pasar dunia, dengan keadaan seperti ini perusahaan-perusahaan multinasional mulai menerapkan strategi yang paling efektif sehingga produknya dapat diterima oleh masyarakat. Persaingan dalam dunia usaha kini bersifat head to head artinya persaingan tidak terjadi antar bangsa melainkan antar perusahaan, baik perusahaan lokal maupun internasional, sehingga perusahaan lokal harus siap bersaing dengan perusahaan internasional untuk menguasai pangsa pasar.

Perkembangan dalam bidang pemasaran telah meningkatkan barang dan jasa yang dikonsumsi oleh masyarakat. Oleh karena itu, perusahaanperusahaan dengan cepat mengubah strategi usaha dan pemasarannya untuk lebih dekat dengan konsumen, mengatasi ancaman persaingan, dan memperkuat keunggulan bersaing.

Persaingan yang semakin kompetitif pada produk-produk minuman dalam kemasan menuntut perusahaan harus melakukan strategi-strategi yang unggul dalam memenangkan persaingan. Industri minuman mempunyai prospek yang cukup baik untuk berkembang sehingga banyak perusahaan yang bersaing dalam industri ini, Pangsa pasar minuman di tingkat ritel menurut jenis seperti disajikan dalam Gambar 1.

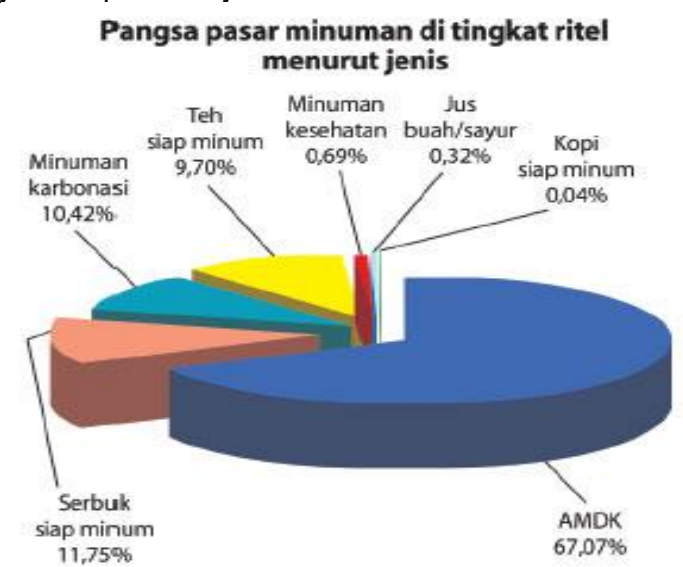

Sumber: WartaEkonomi.com,16 Oktober 2006.

Gambar 1

Pangsa Pasar Minuman di Tingkat Ritel

Gambar 1.1 di atas menunjukan bahwa industri minuman berkarbonasi pangsa pasarnya yaitu sebesar $(10,42 \%)$ masih di bawah industri air minum dalam kemasan (AMDK) sebesar $(67,07 \%)$ dan industri minuman serbuk sebesar $(11,75 \%)$, tetapi tidak menutup kemungkinan pangsa pasar minuman berkarbonasi akan meningkat seiring dengan mulai banyaknya perusahaan yang masuk dalam industri minuman berkarbonasi yang sebelumnya hanya dikuasai oleh merek Coca-Cola Company dan Pepsi Co, perusahaan-perusahaan yang memproduksi minuman berkarbonasi beserta merek yang dipasarkannya disajikan dalam Tabel 1 di bawah ini.

Tabel 1

Data Perusahaan Minuman Berkarbonasi

\begin{tabular}{|c|l|l|}
\hline No & Nama Perusahaan & \multicolumn{1}{c|}{ Merek } \\
\hline 1 & $\begin{array}{l}\text { The Coca-Cola } \\
\text { Company/ Coca-Cola } \\
\text { Indonesia (CCI) }\end{array}$ & $\begin{array}{l}\text { Coca Cola, Sprite, } \\
\text { Fanta Coke, A\&W }\end{array}$ \\
\hline 2 & Pepsico & $\begin{array}{l}\text { Pepsi Cola, Mountain } \\
\text { Dew Mirinda, 7up }\end{array}$ \\
\hline 3 & $\begin{array}{l}\text { PT. Multi Bintang } \\
\text { Indonesia }\end{array}$ & Green Sands, Fit'n Fun \\
\hline 4 & PT. Sinar Sosro & Tabs \\
\hline
\end{tabular}

Sumber: Diolah dari Berbagai Sumber 2007.

Tabel di atas menggambarkan bahwa persaingan industri minuman berkarbonasi di Indonesia saat ini cukup baik, terlihat dengan banyaknya agen tunggal pemegang merek minuman berkarbonasi, sehingga persaingan untuk menguasai pasar minuman berkarbonasi menjadi sulit. Perusahaan Coca-Cola sebagai pemimpin pasar minuman berkarbonasi dengan merek-merek dagangnya yang sudah terkenal sekarang mendapatkan pesaing, tidak hanya dari perusahaan sejenis tetapi juga dari perusahaan non karbonasi, pangsa pasar minuman berkarbonasi disajikan dalam Tabel 2 .

Tabel 2

Total Penjualan dan Market Share Minuman Berkarbonasi

\begin{tabular}{|c|l|l|l|l|c|c|}
\hline \multirow{2}{*}{ No } & \multirow{2}{*}{ Perusahaan } & \multicolumn{3}{|c|}{ Total Penjualan } & $\begin{array}{c}\text { Mark. } \\
\text { Shiliar) }\end{array}$ & $\begin{array}{c}\text { Mark. } \\
\text { Share }\end{array}$ \\
\cline { 3 - 7 } & & $\mathbf{2 0 0 6}$ & $\mathbf{2 0 0 5}$ & $\mathbf{2 0 0 4}$ & $\mathbf{2 0 0 5}$ & $\mathbf{2 0 0 6}$ \\
\hline 1 & $\begin{array}{l}\text { Coca-Cola } \\
\text { Indonesia }\end{array}$ & 46,2 & 42,9 & 32,4 & $41 \%$ & $49 \%$ \\
\hline 2 & Pepsico & 35,15 & 32,56 & 9,26 & $31 \%$ & $38 \%$ \\
\hline 3 & $\begin{array}{l}\text { PT.Multi } \\
\text { Bintang } \\
\text { Indonesia }\end{array}$ & 25,58 & 20.25 & 16,58 & $28 \%$ & $13 \%$ \\
\hline
\end{tabular}

Sumber: Pepsico, Coca-Cola Indonesia, Multi Bintang, 2007

Tabel 2 menunjukan bahwa total penjualan minuman berkarbonasi yang dikuasai tiga perusahaan besar rata-rata mengalami kenaikan, Coca-Cola Indonesia mengalami kenaikan sebesar 3,3\% pada tahun 2005-2006, sedangkan Pepsi Cola mengalami kenaikan sebesar $2,6 \%$ pada tahun 2005-2006, untuk itu Coca-Cola masih 
menguasai pasar minuman berkarbonasi. Pangsa pasar minuman berkarbonasi Coca-Cola sebesar 41\% pada tahun 2005 dan $49 \%$ pada tahun 2006 , untuk Pepsi Cola memperoleh pangsa pasar sebesar 31\% tahun 2005 dan 38\% tahun 2006 dan Multi Bintang Indonesia pangsa pasarnya sebesar $28 \%$ tahun 2005 dan $13 \%$ tahun 2006, dari uraian di atas dapat diketahui bahwa Coca-Cola Indonesia memperoleh penjualan dan pangsa pasar yang lebih besar dari para pesaingnya. Keberhasilan Coca-Cola Indonesia menguasai pasar minuman berkarbonasi disebabkan karena produk-produk cukup beragam dalam kategori minuman berkarbonasi.

Penguasaan merek atau brand share minuman berkarbonasi dapat dilihat pada Tabel 3 sebagai berikut:

Tabel 3

Brand Share Minuman Berkarbonasi

\begin{tabular}{|c|c|c|c|}
\hline Merek & $\mathbf{2 0 0 4}$ & $\mathbf{2 0 0 5}$ & $\mathbf{2 0 0 6}$ \\
\hline Fanta & $62.01 \%$ & $35,5 \%$ & $33,7 \%$ \\
\hline Coca-Cola & $139.53 \%$ & $32,8 \%$ & $28,5 \%$ \\
\hline Sprite & $37.65 \%$ & $2,2 \%$ & $30,9 \%$ \\
\hline Pepsi Cola & $29.90 \%$ & $2,2 \%$ & $0,9 \%$ \\
\hline Green Sands & - & $1,0 \%$ & - \\
\hline F\&N & - & - & $0,9 \%$ \\
\hline
\end{tabular}

Sumber : SWA 15/XXII/27 Juli-9 Agustus 2006.

Ket: Brandshare merupakan merek yang paling sering digunakan (brand use most often).

Tabel 3 menunjukan bahwa brandshare minuman berkarbonasi merek Coca-Cola mengalami penurunan yaitu dari $139,53 \%$ menjadi 32,8 kemudian pada tahun 2006 menjadi $28,5 \%$. Berbeda dengan pesaing utamanya yaitu Fanta meskipun mengalami penurunan akan tetapi penurunannya tidak sebesar penurunan merek Coca-Cola, hal ini menyebabkan pemimpin pasar minuman berkarbonasi tidak dikuasai merek CocaCola melainkan oleh merek Fanta penurunan brand share merek Coca-Cola disebabkan karena strategi yang di terapkan merek Coca-Cola tidak sesuai dengan kondisi dan keadaan pasar minuman berkarbonasi, (SWA 15/XXII/27 Juli-9 Agustus 2006). Keberhasilan Fanta menempati posisi pertama salah satunya yaitu tidak perlu disajikan dingin seperti Coca-Cola dan rasa buah yang mudah diterima masyarakat Indonesia serta rasa Fanta juga lebih bervariasi, sedangkan CocaCola tidak ada variasi dan inovasi seperti yang dilakukan Fanta. Pada Tabel 4 menunjukkan tingkat konsumsi minuman berkarbonasi.

Tabel 4
Tingkat Konsumsi Minuman Berkarbonasi

\begin{tabular}{|l|c|c|c|}
\hline $\begin{array}{c}\text { Merek/ } \\
\text { Produk }\end{array}$ & $\begin{array}{c}\text { Botol } \\
(\mathbf{m l})\end{array}$ & $\begin{array}{c}\text { Kaleng } \\
(\mathbf{m l})\end{array}$ & $\begin{array}{c}\text { Total } \\
(\mathbf{m l})\end{array}$ \\
\hline Fanta & 765 & 617 & 1382 \\
\hline Coca-cola & 752 & 539 & 1291 \\
\hline Sprite & 537 & 371 & 902 \\
\hline Pepsi & 492 & 295 & 787 \\
\hline Tabs & 313 & - & 313 \\
\hline
\end{tabular}

Sumber: Hasil Wawancara dengan pihak Carrefour 2008.

Pada Tabel 4 di atas menunjukkan bahwa tingkat konsumsi minuman berkarbonasi yang paling banyak dikonsumsi oleh konsumen adalah merek Fanta dengan total sebesar 1382/bulan, sedangkan untuk merek Coca-Cola sebesar 1291/bulan, peralihan konsumsi minuman berkarbonasi dari merek Coca-Cola menjadi merek Fanta disebabkan oleh beberapa faktor misalnya strategi yang dijalankan oleh merek Coca-Cola tidak sesuai dengan harapan konsumen, sedangkan untuk merek pesaingnya Fanta menerapkan strategi yang sesuai dengan keinginan konsumen.

Merek minuman berkarbonasi Coca-Cola merupakan merek global akan tetapi di Indonesia sendiri Coca-Cola masih kalah dengan pesaing utamanya yaitu Fanta yang masih satu produksi dengan merek Coca-Cola, Tabel 5 pada menunjukkan Jenis minuman berkarbonasi yang paling disukai dan paling diketahui.

Tabel 5

Jenis Minuman Berkarbonasi yang

Paling Disukai dan Diketahui

\begin{tabular}{|l|c|c|}
\hline \multicolumn{1}{|c|}{ Merek } & Paling Disukai & Paling Diketahui \\
\hline Fanta & $25 \%$ & $85 \%$ \\
\hline Coca-Cola & $23 \%$ & $85 \%$ \\
\hline Sprite & $16 \%$ & $72 \%$ \\
\hline Pepsi & $9 \%$ & $44 \%$ \\
\hline Tebs & $1 \%$ & $11 \%$ \\
\hline Mirinda & $1 \%$ & $3 \%$ \\
\hline 7up & $1 \%$ & $3 \%$ \\
\hline F\&N & $1 \%$ & $5 \%$ \\
\hline
\end{tabular}

Sumber: Marketing 01/VII/Januari 2008

Tabel 5 menunjukan bahwa merek minuman berkarbonasi yang paling disukai artinya paling banyak dikonsumsi adalah merek Fanta dengan nilai sebesar $25 \%$ dan Coca-Cola $23 \%$, sedangkan sisanya dikuasai merek lain, itu artinya bahwa sebagian besar konsumen lebih memilih merek Fanta dari pada merek minuman berkarbonasi Coca-Cola, kalau Coca-Cola tidak melakukan strategi yang dapat menarik minat konsumen untuk melakukan pembelian maka dipastikan pangsa 
pasar minuman berkarbonasi akan tetap dikuasai merek Fanta (Marketing 01/VII/Januari 2008).

Peralihan market leader minuman berkarbonasi dari merek Coca-Cola menjadi merek Fanta, disebabkan banyaknya faktor-faktor yang menjadi pertimbangan konsumen sebelum memutuskan membeli seperti kualitas produk, harga, kemudahan dalam mendapatkan produk dan keyakinan bahwa merek yang dikonsumsi adalah merek yang paling memuaskan dan paling sesuai dengan kebutuhan kita dibandingkan dengan merek lain.

Keputusan pembelian konsumen terhadap suatu produk merupakan salah satu hal yang dianggap penting untuk diperhatikan oleh setiap pemasar, karena hal tersebut merupakan suatu langkah awal yang menentukan apakah konsumen akan benar-benar membeli produk atau tidak, di mana keputusan ini dapat berubah-ubah dengan cepat sesuai dengan pengaruh yang berasal dari dalam ataupun dari luar dirinya.

Faktor lain yang menyebabkan konsumen memilih suatu produk adalah dengan melakukan diferensiasi, Porter (1994:128) mendefinisikan "differentiation is a firm differentiates it self from its competitors if it can be unique at something that is valuable to buyers", maksudnya bahwa perbedaan yang kita ciptakan haruslah mendatangkan value yang bermakna bagi pelanggan, dengan keunggulan produk yang khas akan menjadi daya tarik bagi konsumen dalam keputusan pembelian.

Merek Coca-Cola mendiferensiasikan produknya salah satunya dengan merubah ukuran kemasan menjadi lebih kecil, dan rasa yang khas minuman berkarbonasi, sedangkan pesaingnya fanta melakukan diferensiasi dari rasa yang ditawarkan dimana rasa minuman berkarbonasi merek Fanta sangat bervariasi dengan percampuran rasa soda dan buah-buahan dan terbukti akhirnya Fanta dapat menguasai pasar minuman berkarbonasi (www.swa.co.id).

Strategi diferensiasi terutama dari segi rancangan, Coca-Cola memasarkan minuman berkarbonasi dengan gaya baru yaitu Coca-Cola Zero tanpa gula dengan rasa khas Coca-Cola, sedangkan Fanta memasarkan lebih banyak varian rasa yang ditawarkan sehingga konsumen mudah memilih rasa yang sesuai dengan seleranya (Marketing 01/VII/Januari 2008).

Kemudian strategi lain yang dilakukan oleh merek minuman berkarbonasi yaitu dengan melakukan positioning, strategi positioning merupakan strategi penempatan posisi produk atau merek terhadap target market-nya.

Strategi seperti ini jelas menguntungkan karena para pesaing akan sulit masuk memenuhi kebutuhan di pasar seperti disajikan dalam Tabel 6 di bawah ini.

Tabel 6

Target Sasaran Minuman Berkarbonasi

\begin{tabular}{|l|c|c|}
\hline Nama Produk & Target Sasaran & $\begin{array}{c}\text { Usia } \\
\text { (thn.) }\end{array}$ \\
\hline Fanta & Belia dan Remaja & $12-18$ \\
\hline Coca-cola & Menengah & $18-30$ \\
\hline Sprite & Dewasa Ke-atas & $30-45$ \\
\hline Tabs & $\begin{array}{c}\text { Remaja dan Eksekutuf } \\
\text { Muda yang Dinamis }\end{array}$ & $16-35$ \\
\hline Pepsi & Remaja dan Dewasa & $15-40$ \\
\hline Green Sands & Menengah Ke-atas & $17-45$ \\
\hline
\end{tabular}

Sumber: Diolah dari Swa Online, Juli 2005

Tabel 6 menunjukan target sasaran produkproduk minuman berkarbonasi, dimana produk Fanta menetapkan target sasarannya adalah konsumen usia belia remaja sehingga Fanta memposisikan keceriaan (fun) sebagai ciri khas dari produknya. Untuk produk Coca-Cola menargetkan usia menengah yang lebih menyukai rasa asli minuman berkarbonasi atau taste CocaCola (www.swa.co.id). Strategi yang yang disebutkan di atas merupakan strategi yang umum telah dilakukan oleh produsen minuman berkarbonasi, akan tetapi untuk strategi in store display Coca-Cola merupakan merek yang paling banyak di temui di dalam outlet-outlet modern maupun tradisional.

Strategi in store display adalah strategi yang paling tepat dilakukan oleh Coca-Cola, karena para pesaing minuman berkarbonasi lainnya jarang yang menerapkan startegi in store display, sehingga dengan strategi ini diharapkan Coca-Cola mampu untuk memperbaiki penjualannya yang saat ini mengalami penurunan. Strategi in store display sangat tepat mengingat pertumbuhan toko ritel di Indonesia berpotensi untuk terus berkembang karena banyaknya masyarakat yang lebih memilih untuk melakukan pembelian di outletoutlet modern.

Tabel 7 di halaman selanjutnya menunjukkan rata-rata pengunjung Supermarket atau Hipermarket di kota Bandung. 


\section{StrategiC}

Tabel 7

Rata-rata Pengunjung Supermarket dan Hypermarket di Kota Bandung

\begin{tabular}{|c|l|c|}
\hline No & Nama Supermarket & $\begin{array}{c}\text { Rata-Rata } \\
\text { Kunjungan }\end{array}$ \\
\hline 1 & Carrefour Sukajadi & 30.000 Orang/Hari \\
\hline 2 & $\begin{array}{l}\text { Bandung Super Mall } \\
\text { (BSM) }\end{array}$ & 40.000 Orang/Hari \\
\hline 3 & Matahari & 2.000 Orang /Hari \\
\hline & $\begin{array}{l}\text { Bandung Indah Plaza } \\
\text { (BIP) }\end{array}$ & 15.000 Orang/Hari \\
\hline
\end{tabular}

Sumber: Modifikasi dari Hasil Wawancara dengan Carrefour 2008 dan Berita Pikiran Rakyat Bandung 2007

Tabel 7 di atas menunjukkan bahwa rata-rata pengunjung Carrefour Paris Van Java Jl. Sukajadi Bandung hampir mencapai 30.000 orang pada hari-hari biasa, sedangkan untuk hari libur kerja jumlah pengunjung bisa lebih banyak lagi, sedangkan untuk jumlah pengunjung Bandung Super Mall (BSM) hampir mencapai 40.00 orang/per hari untuk hari-hari jam kerja sedangkan untuk hari libur bisa mencapai 50.000 orang/per hari (Pikiran Rakyat, 2 Mei 2007).

Perusahaan Coca-Cola terus melakukan promosi secara besar-besaran tidak hanya above the line tetapi juga melakukan promosi di outletoutlet modern maupun tradisional. Prada Sugarda Customer\&Comercial Leadership Manager PT Coca-Cola Indonesia dalam Marketing 08/VII/Agustus 2007, di outlet modern atau tradisional Coca-Cola hadir dengan berbagai macam iklan misalnya dengan gambar-gambar di dinding, pilar, poster, troli, banner, selain itu juga karena riset mengatakan $90 \%$ konsumen Indonesia lebih menyukai Coca-Cola dalam keadaan dingin maka disediakan mesin pendingin (Cooler) di setiap outlet, cooler (mesin pendingin) Coca-Cola yang ada di outlet modern maupun warung tradisional diberikan secara gratis kepada outlet dan jumlahnya sudah ratusan ribu, dengan rata-rata penambahan tiap tahunnya sekitar 10.000 unit.

Display Coca-Cola yang di tempatkan di Outletoutlet modern seperti Giant dan Carrefour dengan bentuk yang unik dan fariasi warna yang khas merek Coca-Cola. Coca-Cola bersaing tidak hanya dengan minuman berkarbonasi tetapi dengan minuman dalam kemasan lainnya (ready-to-drink), untuk itu Coca-Cola menerapkan strategi penempatan display, dengan strategi ini diharapkan Coca-Cola dapat menguasai kembali pangsa pasar minuman berkarbonasi yang sampai saat ini masih dikuasai merek Fanta (Marketing 08/VII/Agustus 2007).

Pajangan toko (in store display) tata letak barang-barang dagangan dan tempat sangat penting bagi pengecer sebagai suatu teknik penjualan, Tata letak yang baik sering diibaratkan mesin penjualan, tata letak dan tempat barang dagangan disebut display, display berarti usaha mendorong perhatian dan minat konsumen pada toko atau produk dan keinginan membeli melalui daya tarik penglihatan secara langsung, penyelenggaraan display yang efektif akan meningkatkan penjualan dan dapat merangsang minat membeli konsumen terhadap suatu produk (Jefkins, 1997:134).

Berdasarkan uraian di atas, dapat dirumuskan beberapa masalah yang akan diteliti sebagai berikut:

1. Bagaimana gambaran in store display minuman ringan berkarbonasi merek CocaCola pada Carrefour Paris Van Java.

2. Bagaiman gambaran keputusan pembelian minuman ringan berkarbonasi merek CocaCola pada Carrefour Paris Van Java.

3. Seberapa besar pengaruh in store display terhadap keputusan pembelian konsumen minuman ringan berkarbonasi pada merek Coca-cola di Carrefour Paris Van Java

\section{KERANGKA PEMIKIRAN}

Persaingan dalam era globalisasi saat ini, menuntut setiap perusahaan atau unit-unit bisnis untuk menciptakan keunggulan bersaing yang didukung dengan penerapan strategi pemasaran yang tepat untuk menciptakan dan memperoleh pelanggan potensial, kemudian mempertahankannya sebagai modal kelangsungan hidup perusahaan. Strategi pemasaran yang tepat merupakan kombinasi dari elemen-elemen pemasaran yang dirancang untuk memperoleh pasar sasaran. Kotler (2005:17), menyatakan bahwa "bauran pemasaran adalah seperangkat alat pemasaran yang digunakan perusahaan untuk terus-menerus mencapai tujuan pemasarannya di pasar sasaran".

Kotler dan Armstrong (2006:48) mengelompokkan komponen bauran pemasaran menjadi empat variabel yang disebut "the four Ps" yaitu: 
1. Product

2. Price

3. Place

4. Promotion

Bauran pemasaran terdiri dari segala sesuatu yang dapat dilakukan perusahaan untuk mempengaruhi permintaan produknya. Kemungkinan yang banyak itu dapat digolongkan menjadi empat kelompok variabel yang dikenal sebagai "empat P" yang terdiri dari produk, harga, distribusi, dan promosi. Promosi merupakan aktivitas mengkomunikasikan keunggulan produk dan membujuk pelanggan sasaran untuk membelinya.

Kotler dan Armstrong (2006:48) menyatakan bahwa "Promotions means activities that merits of the product and persuade market to buy it". Promosi merupakan aktivitas yang mengkomunikasikan keunggulan produk serta membujuk pasar sasaran untuk membelinya.

Berdasarkan pendapat di atas dapat disimpulkan bahwa bahwa promosi merupakan aktivitas komunikasi pemasaran yang bersifat non personal yang berusaha menyebarkan, informasi, mempengaruhi, membujuk dan atau mengingatkan pasar sasaran atas perusahaan dan produknya agar bersedia menerima, membeli dan loyal pada produk yang ditawarkan perusahaan yang bersangkutan.

Kotler dan Armstrong (2006:401), bahwa elemen promosi itu ada beberapa elemen, yaitu:

1. Personal Selling

2. Advertising

3. Sales Promotion

4. Pubic Relation

5. Direct Marketing

Menurut Fandy Tjiptono, Gregorius Chandra dan Dedi Adriana (2008:546) Sales promotion merupakan segala bentuk penawaran atau insentif jangka pendek yang ditujukan bagi pembeli, pengecer atau pedagang grosir dan dirancang untuk memperoleh respons spesifik dan segera.

Menurut definisi sales promotion di atas dapat diambil kesimpulan, sales promotion adalah bentuk persuasi langsung melalui penggunaan berbagai insentif, umumnya berjangka pendek, yang dapat diatur untuk merangsang pembelian produk dengan segera atau meningkatkan jumlah barang yang dibeli konsumen atau pedagang.
Literatur pemasaran mendokumentasi beberapa definisi komunikasi point-of purchase, menurut Shimp dalam Fandy Tjiptono, Gregorius Chandra dan Dedi Adriana (2008:569) misalnya, komunikasi $P O P$ adalah elemen promosi seperti pajangan, poster, petunjuk/tanda, dan berbagai materi promosi lainnya di dalam toko yang dirancang untuk mempengaruhi pilihan pelanggan pada momen pembelian.

Berdasarkan literatur di atas mengenai komunikasi POP, maka dalam penelitian ini komunikasi POP merupakan suatu program promosi penjualan yang dibuat semenarik mungkin dengan tujuan untuk menarik minat konsumen terhadap apa yang dilihatnya dalam pajangan yang ada di dalam toko.

Jefkins (1997:134) Display (pajangan toko) merupakan tata letak dan tempat barang dagangan, display berarti usaha mendorong perhatian dan minat konsumen pada toko/produk dan mendorong keinginan membeli.

Julian Cummins dan Roddy Mullin (2004:45), Display dapat dilakukan dalam beragam bentuk: tambahan rak pajangan, ujung gondola (ujung dari deretan rak), display etalase, display stiker di pintu, penggunaan petunjuk arah lokasi barang, leaflet, serta pemasangan rak display khusus (dumpbin).

Berdasarkan literatur di maka dapat disimpulkan In store display adalah suatu proses komunikasi/promosi yang dilakukan di dalam toko/outlet dengan menggunakan berbagai bentuk pajangan yang dapat menarik minat konsumen.

Keputusan untuk membeli timbul karena adanya penilaian yang objektif atau dorongan emosi. Keputusan untuk bertindak adalah hasil dari serangkaian aktivitas dan rangsangan mental serta emosional. Menurut Griffin dan Ebert (2006:283) mengemukakan definisi keputusan pembelian sebagai: "Buy' decisions are based on rational motives, emotional motives, or both. Rational motives involve the logical evaluation of product attributes: cost, quality, and usefulness. Emotional motives involve non objective factors and include sociability, imitation of others, and aesthetics." Artinya: Keputusan pembelian didasarkan pada motif rasional, motif emosional, atau keduanya. Motif rasional melibatkan penilaian logis atas atribut produk, kualitas biaya, dan kegunaan. Motif emosional melibatkan faktor non objective termasuk keramahan, peniruan dari orang lain, dan estetika. 
Keputusan pembelian menurut Sutisna (2004:18): Dalam persfektif pengaruh perilaku, pilihan keputusan merepresentasikan perilaku yang dihasilkan dari adanya stimuli yang mampu menguatkan pengalaman masa lalu selama proses pencarian informasi. Dari pengalaman masa lalu konsumen dapat membedakan informasi yang menguatkan atau melemahkan pilihan keputusan.

Berdasarkan berbagai defenisi yang disampaikan oleh para ahli di atas, dapat ditarik kesimpulan bahwa yang dimaksud dengan perilaku pembelian konsumen adalah perilaku konsumen dalam membeli produk atau menggunakan produk yang dikonsumsi secara pribadi yang dipengaruhi oleh lingkungan sekitarnya baik internal maupun ekstrnal.

Pembuatan keputusan yang dilakukan oleh konsumen berbeda-beda sesuai dengan jenis keputusan pembelian. Semakin kompleks keputusan untuk membeli sesuatu, kemungkinan akan lebih banyak melibatkan pertimbangan pembeli. Kotler dan Armstrong (2006:146) membedakan empat tipe perilaku pembelian berdasarkan derajat keterlibatan konsumen dalam membeli dan derajat perbedaan diantara beberapa merek. Keempat tipe tersebut terlihat pada Tabel 8 di bawah ini.

Tabel 8

Tipe-Tipe Perilaku Keputusan Pembelian

\begin{tabular}{|l|l|l|}
\hline & High Involvement & Low Involvement \\
\hline $\begin{array}{l}\text { Significant } \\
\text { Differences } \\
\text { Between Brands }\end{array}$ & $\begin{array}{l}\text { Complex Buying } \\
\text { Behavior }\end{array}$ & $\begin{array}{l}\text { Variety-seeking } \\
\text { buying Behavior }\end{array}$ \\
\hline $\begin{array}{l}\text { Few Differences } \\
\text { Between Brands }\end{array}$ & $\begin{array}{l}\text { Dissonance- } \\
\text { reducing Buying } \\
\text { Behavior }\end{array}$ & $\begin{array}{l}\text { Habitual buying } \\
\text { Behavior }\end{array}$ \\
\hline
\end{tabular}

Sumber : Kotler dan Armstrong (2006:146)

Perbedaan besar antara merek (significant differences between brands) artinya bahwa konsumen memandang perbedaan yang signifikan di antara berbagai merek (few differences between brands), konsumen hanya melihat sedikit perbedaan dalam merek-merek dan tidak adanya perbedaan merek yang signifikan.

Memahami perilaku konsumen tidaklah mudah karena konsumen memutuskan pembelian tertentu yang berbeda dan sangat bervariasi dalam usia, pendapatan, tingkat pendidikan, dan selera. Adalah tugas dari pemasar untuk meneliti faktorfaktor yang mendasari konsumen dalam memilih salah satu atau beberapa diantara jajaran produk yang ditawarkan perusahaan. Kemudian melakukan pembelian. Akhirnya individu memiliki persepsi atau pandangan tertentu apakah ia mau membeli atau tidak, dan barang apa yang akan dibeli, melalui tahap-tahap proses pengambilan keputusan membeli.

Keputusan untuk membeli timbul karena adanya penilaian objektif atau karena adanya dorongan emosi, keputusan untuk bertindak adalah hasil dari serangkaian aktifitas yang dapat dideskripsikan dalam proses pembelian. Rangkaian proses keputusan pembelian konsumen menurut Kotler dan Amstrong (2006: 147) adalah sebagai berikut.

1. Pengenalan Kebutuhan. Proses pembelian dimulai saat pembeli mengenali sebuah masalah atau kebutuhan.

2. Pencarian Informasi. Minat utama pemasar berfokus pada sumber-sumber informasi utama yang menjadi acuan konsumen dan pengaruh relatif tiap sumber tersebut terhadap keputusan pembelian selanjutnya.

3. Evaluasi Alternatif. Tidak ada proses evaluasi tunggal sederhana yang digunakan oleh semua konsumen atau oleh satu konsumen dalam semua situasi pembelian. Terdapat beberapa proses evaluasi keputusan, dan model-model yang terbaru memandang proses evaluasi konsumen sebagai proses yang berorientasi kognitif. Yaitu, model tersebut menganggap konsumen membentuk penilaian atas produk dengan sangat sadar dan rasional.

4. Keputusan Pembelian. Konsumen membentuk preferensi atas merek-merek yang ada di dalam kumpulan pilihan (tahap evaluasi). Konsumen tersebut juga dapat membentuk niat untuk membeli merek yang paling disukai.

5. Perilaku Pasca Pembelian. Menurut Gibson, et al. dalam Fandy Tjiptono dan Anastasia Diana (2003:186) mengemukakan proses pengambilan keputusan yang dapat diterapkan untuk menangani tipe keputusan diprogram maupun yang tidak diprogram. Proses ini terdiri atas tujuah langkah, yaitu:

a. Menetapkan tujuan dan sasaran spesifik

b. Identifikasi masalah

c. Mengembangkan alternatif-alternatif

d. Evaluasi terhadap masing-masing alternatif

e. Memilih alternatif yang terbaik

f. Melaksanakan keputusan

g. Melakukan pengendalian dan evaluasi

Setelah membeli produk, konsumen akan mengelami level kepuasan atau ketidakpuasan 


\section{StrategiC}

tertentu. Tugas pemasar tidak berakhir begitu saja ketika produk dibeli. Para pemasar harus memantau kepuasan pasca pembelian, tindakan pasca pembelian, dan pemakaian produk pasca pembelian.

\section{METODE PENELITIAN}

Penelitian ini menggunakan pendekatan manajemen pemasaran khususnya mengenai bauran pemasaran yang menitikberatkan kepada in store display yang merupakan bagian dari point of purchase. Objek penelitian yang menjadi variabel bebas atau indipendent variable adalah in store display yang terdiri dari branding, durability, flexibility, modularity, visibility \& accessibility, dan creatifity. Kemudian objek penelitian yang menjadi variabel terikat atau dependent variable adalah keputusan pembelian yang terdiri dari Pemilihan Produk, Pemilihan Merek, Pemilihan Saluran Pembelian, Waktu Pembelian dan Jumlah Pembelian.

Berdasarkan variabel-variabel yang diteliti maka jenis penelitian ini adalah penelitian deskriptif dan verifikatif. Traver Travens dalam Husein Umar (2001:21) menjelaskan bahwa penelitian dengan menggunakan metode deskriptif adalah penelitian yang dilakukan untuk mengetahui nilai variabel mandiri, baik satu variabel atau lebih (independent) tanpa membuat perbandingan atau menghubungkan dengan variabel lain. Penelitian deskriptif bertujuan untuk memperoleh deskripsi atau gambaran mengenai pelaksanaan in store display yang dilaksanakan perusahaan yang ditimbulkan dari produk yang diterima konsumen sebagai pengguna produk terhadap keputusan pembeliannya. Sedangkan penelitian verifikatif, menurut Suharsimi Arikunto (2006:7) pada dasarnya ingin menguji kebenaran pengumpulan data di lapangan. Dalam penelitian ini akan diuji mengenai kebenaran hipotesis yang dilaksanakan melalui pengumpulan data di lapangan, dalam hal ini penelitian verifikatif bertujuan untuk mengetahui pengaruh in store display terhadap keputusan pembelian.

Berdasarkan jenis penelitian di atas yaitu deskriptif dan verifikatif yang dilaksanakan melalui pengumpulan data di lapangan, maka metode yang digunakan dalam penelitian ini adalah explanatory survey. Menurut Ker Linger (Sugiyono, 2005:7), metode survei yaitu metode penelitian yang dilakukan pada populasi besar maupun kecil, tetapi data yang dipelajari adalah data dari sample yang diambil dari populasi tersebut, sehingga ditemukan kejadian-kejadian relatif, distribusi, dan hubungan-hubungan antar variabel sosiologis maupun psikologis.

Penelitian ini dilakukan pada waktu kurang dari satu tahun, maka metode yang digunakan adalah cross sectional method yaitu metode penelitian dengan cara mempelajari objek dalam kurun waktu tertentu (tidak berkesinambungan dalam jangka waktu panjang). (Husein Umar, 2001:45).

Populasi dalam penelitian ini adalah konsumen minuman berkarbonasi merek Coca-Cola di Carrefour Paris Van Java JI Sukajadi Bandung dengan rata-rata jumlah konsumen sebanyak 1.291 orang per bulan (Sumber: Hasil Wawancara dengan pihak Carrefour 2008). Berdasarkan teknik penarikan sampel secara systematic random sampling dan dengan menggunakan rumus Slovin diperoleh sampel sebesar 93 sampel, namun untuk meningkatkan keakuratan maka jumlah sampel yang diteliti ditambah sehingga berjumlah 100 sampel. Menurut Winarno Surakhmad (1998:100), untuk jaminan ada baiknya sampel selalu ditambah sedikit lagi dari jumlah matematik.

Tabel 9 di bawah ini menyajikan operasionalisasi variabel penelitian.

Tabel 9

Operasionalisasi Variabel Penelitian

\begin{tabular}{|l|l|l|l|l|}
\hline \multicolumn{1}{|c|}{ Variabel } & Sub variabel & \multicolumn{1}{|c|}{ Indikator } & \multicolumn{1}{c|}{ Ukuran } & \\
\hline $\begin{array}{l}\text { In Store } \\
\text { Display } \\
\text { (X) }\end{array}$ & & & & \\
\hline \multirow{4}{*}{ Branding } & $\begin{array}{l}\text { Nama merek atau logo jelas terpampang di } \\
\text { rak pajangan }\end{array}$ & $\begin{array}{l}\text { Tingkat kejelasan nama merek atau } \\
\text { logo sebuah produk yang terpasang } \\
\text { di rak pajangan }\end{array}$ & Ordinal \\
\cline { 3 - 5 } & Brand recognition pada konsumen & $\begin{array}{l}\text { Tingkat kemudahan mengenali } \\
\text { merek di rak pajangan }\end{array}$ & Ordinal \\
\hline \multirow{3}{*}{ Durability } & Umur ekonomis pajangan & Tingkat umur ekonomis pajangan. & Ordinal \\
\cline { 3 - 5 } & Kualitas bahan yang digunaka & $\begin{array}{l}\text { Tingkat keawetan bahan yang } \\
\text { digunakan }\end{array}$ & Ordinal \\
\cline { 3 - 5 } & Stabilitas pajanga & Tingkat kekuatan pajangan & Ordinal \\
\hline
\end{tabular}




\section{StrategiC}

\begin{tabular}{|c|c|c|c|c|}
\hline Variabel & Sub variabel & Indikator & Ukuran & Skala \\
\hline & Flexibility & $\begin{array}{l}\text { Kesesuaian dengan lingkungan dan konsisi } \\
\text { gerai pengecer }\end{array}$ & $\begin{array}{l}\text { Tingkat kesesuaian dengan bentuk } \\
\text { ruangan toko }\end{array}$ & Ordinal \\
\hline & \multirow{3}{*}{ Modularity } & Kemudahan penggantian rak & $\begin{array}{l}\text { Tingkat kemudahan penggantian } \\
\text { rak pajangan }\end{array}$ & Ordinal \\
\hline & & Rak sesuai dengan produk/kemasan baru & $\begin{array}{l}\text { Tingkat kesesuaian rak pajangan } \\
\text { dengan produk/kemasan baru }\end{array}$ & Ordinal \\
\hline & & Dapat diperluas & Tingkat perluasan rak pajangan & Ordinal \\
\hline & \multirow{3}{*}{$\begin{array}{l}\text { Visibility \& } \\
\text { Accessibility }\end{array}$} & Kebersihan unit pajangan & $\begin{array}{l}\text { Tingkat kebersihan unit rak } \\
\text { pajangan }\end{array}$ & Ordinal \\
\hline & & Penataan kategori dan item produk & $\begin{array}{l}\text { Tingkat penataan kategori dan item- } \\
\text { item produk }\end{array}$ & Ordinal \\
\hline & & $\begin{array}{l}\text { Kemudahan menjangkau produk dalam rak } \\
\text { pajangan }\end{array}$ & $\begin{array}{l}\text { Tingkat kemudahan menjangkau } \\
\text { produk dalam rak pajangan }\end{array}$ & Ordinal \\
\hline & \multirow{2}{*}{ Creativity } & Keunikan desain unit pajangan & $\begin{array}{l}\text { Tingkat keunikan desain unit } \\
\text { pajangan }\end{array}$ & Ordinal \\
\hline & & Keunikan bentuk unit pajangan & Tingkat keunikan bentuk pajangan & Ordinal \\
\hline \multicolumn{5}{|l|}{$\begin{array}{l}\text { Loyalitas } \\
\text { Pelanggan } \\
\text { (Y) }\end{array}$} \\
\hline & \multirow{3}{*}{$\begin{array}{l}\text { Pemilihan } \\
\text { Produk }\end{array}$} & Pembelian berdasarkan kualitas & $\begin{array}{l}\text { Tingkat pembelian produk } \\
\text { berdasarkan kualitas }\end{array}$ & Ordinal \\
\hline & & Pembelian berdasarkan desain & $\begin{array}{l}\text { Tingkat pembelian produk } \\
\text { berdasarkan desain }\end{array}$ & Ordinal \\
\hline & & Pembelian berdasarkan fitur & $\begin{array}{l}\text { Tingkat pembelian produk } \\
\text { berdasarkan fitur }\end{array}$ & Ordinal \\
\hline & \multirow{2}{*}{$\begin{array}{l}\text { Pemilihan } \\
\text { Merek }\end{array}$} & Pembelian berdasarkan kepercayaan & $\begin{array}{l}\text { Tingkat pembelian produk } \\
\text { berdasarkan kepercayaan terhadap } \\
\text { merek }\end{array}$ & Ordinal \\
\hline & & Pembelian berdasarkan popularitas merek & $\begin{array}{l}\text { Tingkat pembelian produk } \\
\text { berdasarkan popularitas merek }\end{array}$ & \\
\hline & $\begin{array}{l}\text { Pemilihan } \\
\text { Saluran } \\
\text { Pembelian } \\
\end{array}$ & Pembelian berdasarkan saluran pembelian & $\begin{array}{l}\text { Tingkat pembelian produk } \\
\text { berdasarkan kedekatan dengan } \\
\text { saluran pembelian }\end{array}$ & \\
\hline & \multirow{2}{*}{$\begin{array}{l}\text { Waktu } \\
\text { Pembelian }\end{array}$} & $\begin{array}{l}\text { Pembelian berdasarkan ketidakteraturan } \\
\text { waktu pembelian }\end{array}$ & $\begin{array}{l}\text { Tingkat pembelian produk } \\
\text { berdasarkan waktu pembelian yang } \\
\text { tidak teratur }\end{array}$ & \\
\hline & & $\begin{array}{l}\text { Pembelian berdasarkan keteraturan waktu } \\
\text { pembelian }\end{array}$ & $\begin{array}{l}\text { Tingkat pembelian produk } \\
\text { berdasarkan waktu pembelian yang } \\
\text { teratur }\end{array}$ & \\
\hline & \multirow{4}{*}{$\begin{array}{l}\text { Jumlah } \\
\text { pembelian }\end{array}$} & \multirow{2}{*}{ Jumlah pembelian untuk diri sendiri } & $\begin{array}{l}\text { Tingkat pembelian produk } \\
\text { berdasarkan jumlah pembelian untuk } \\
\text { kebutuhan diri sendiri }\end{array}$ & \\
\hline & & & $\begin{array}{l}\text { Tingkat pembelian produk } \\
\text { berdasarkan jumlah pembelian untuk } \\
\text { saat ini dan cadangan }\end{array}$ & \\
\hline & & \multirow{2}{*}{$\begin{array}{l}\text { Jumlah pembelian untuk diri sendiri dan } \\
\text { keluarga }\end{array}$} & $\begin{array}{l}\text { Tingkat pembelian produk } \\
\text { berdasarkan jumlah pembelian untuk } \\
\text { diri sendiri dan keluarga }\end{array}$ & \\
\hline & & & $\begin{array}{l}\text { Tingkat pembelian produk } \\
\text { berdasarkan jumlah pembelian untuk } \\
\text { diri sendiri dan keluarga, saat ini dan }\end{array}$ & \\
\hline
\end{tabular}

Sumber : Berdasarkan Hasil Pengolahan Data dan Referensi Buku

\section{HASIL PENELITIAN DAN PEMBAHASAN}

Hasil penelitian dan pembahasan akan disajikan secara terurut. Dimulai dengan rekapitulasi tanggapan responden terhadap variabel penelitian, kemudian pengujian hipotesis, dan diakhiri dengan penyajian mengenai implikasi penelitian ini terhadap bidang kajian yang diteliti.

\section{REKAPITULASI TANGGAPAN RESPON- DEN TERHADAP VARIABEL PENELITIAN}

Variabel yang diteliti pada penelitian ini adalah in store display yang terdiri dari branding, durability, flexibility, modularity, visibility\& accessibility dan creatifity serta keputusan pembelian yang terdiri dari pemilihan produk, pemilihan merek, pemilihan berdasarkan saluran pembelian, pemilihan berdasarkan waktu pembelian dan pemilihan berdasarkan jumlah pembelian.

Pada penelitian ini diteliti tanggapan responden yang terdiri dari 100 orang mengenai variabelvariabel tersebut melalui penyebaran kuesioner.

\section{Variabel In Store Display}

Penjelasan dari masing-masing dimensi in store display dirangkum dalam tabel rekapitulasi yang tercantum pada Tabel 10 sehingga dapat 


\section{StrategiC}

dilihat perbandingan total skor pada masing- masing dimensi tersebut.

Tabel 10

Rekapitulasi Skor Tanggapan Responden terhadap In Store Display

\begin{tabular}{|c|c|c|c|c|}
\hline No & Variabel/Dimensi & & Perolehan Skor & Rata-Rata \\
\hline \multirow{4}{*}{1} & Branding & & & \\
\hline & Nama merek atau logo jelas terpampang di rak pajangan & & 378 & \\
\hline & Brand recognition pada konsumen & & 399 & \\
\hline & & ub total & 777 & 388,5 \\
\hline \multirow{6}{*}{2} & Durability & & & \\
\hline & $\begin{array}{l}\text { Tingkat frekuensi penggunaan NSP } 1212 \text { setelah adanya premium } \\
\text { (diskon) }\end{array}$ & & 276 & \\
\hline & Umur ekonomis pajangan & & 379 & \\
\hline & Kualitas bahan yang digunakan & & 377 & \\
\hline & Stabilitas pajangan & & 380 & \\
\hline & & ub total & 1136 & 378,8 \\
\hline \multirow{3}{*}{3} & Flexibility & & & \\
\hline & Kesesuaian dengan lingkungan dan kondisi gerai pengecer & & 357 & \\
\hline & & ub total & 357 & 357 \\
\hline \multirow{5}{*}{4} & Modularity & & & \\
\hline & Kemudahan penggantian rak & & 370 & \\
\hline & Rak sesuai dengan produk/kemasan baru & & 340 & \\
\hline & Dapat diperluas & & 369 & \\
\hline & & sub total & 1079 & 359,7 \\
\hline \multirow{5}{*}{5} & Visibility\&Accessibility & & & \\
\hline & Kebersihan unit pajangan & & 360 & \\
\hline & Penataan kategori dan item produk & & 351 & \\
\hline & Kemudahan menjangkau produk dalam rak pajangan & & 363 & \\
\hline & & ub total & 1074 & 358 \\
\hline \multirow{5}{*}{6} & Creatifity & & & \\
\hline & Keunikan desain unit pajangan & & 351 & \\
\hline & Keunikan bentuk unit pajangan & & 356 & \\
\hline & & ub total & 707 & 353,5 \\
\hline & & Total & 5130 & \\
\hline \multicolumn{5}{|c|}{ Sumber: Berdasarkan Hasil Pengolahan Data 2008} \\
\hline \multicolumn{2}{|r|}{$\begin{array}{l}\text { Secara keseluruhan variabel in store display } \\
\text { oat diketahui kedudukannya berdasarkan skor } \\
\text { ig di dapat berdasarkan data dari tabel di atas, }\end{array}$} & \multicolumn{3}{|c|}{$\begin{array}{l}\Rightarrow \text { Skor Terendah } \times \text { Jumlah Butir Item } x \\
\text { Jumlah Pengguna } \\
\Rightarrow 1 \times 14 \times 100=1400\end{array}$} \\
\hline
\end{tabular}

di mana nilai-nilai tersebut dibandingkan dengan kriteria skor standar, yang di dapat melalui perhitungan skor ideal (criterium) dan skor terkecil, sehingga melalui skor standar tersebut dapat diketahui daerah kontinium yang menunjukkan wilayah ideal dari variabel in store display, hal tersebut dapat dicarai dengan rumus menurut Sugiono (2006:94) sebagai berikut: Mencari skor ideal In Store Display

Skor ideal $\longleftrightarrow \begin{aligned} & \text { Skor Tertinggi } x \text { Jumlah Butir Item } x \\ & \text { Jumlah Pengguna }\end{aligned}$
Skor ideal $\longleftrightarrow \quad 5 \times 14 \times 100=7000$
Mencari skor Terendah In Store Display

Mencari Panjang Interval Kelas In Store Display

\begin{tabular}{|l} 
Panjang Interval Kelas $\longleftrightarrow \begin{array}{l}\text { Skor Ideal : Banyaknya } \\
\text { Kelas Interval }\end{array}$ \\
Panjang Interval Kelas $\longrightarrow$ 7000: $5=1400$
\end{tabular}

Berdasarkan jumlah skor hasil pengumpulan data in store display adalah 5130 lihat Tabel 4.24, dengan demikian maka in store display menurut persepsi 100 responden adalah $(5130: 7000) x$ $100 \%=73,3 \%$.

Nilai 5130 sesuai dengan data penelitian yaitu termasuk dalam kategori sedang dan tinggi tetapi lebih mendekati tinggi, jadi in store display minuman berkarbonasi merek Coca-Cola dalam kategori tinggi atau baik.

\section{Variabel Keputusan Pembelian}


Pada penelitian ini terdapat hipotesis yang diuji yaitu pengaruh in store display terhadap keputusan pembelian. Pengujian dilakukan dengan menggunakan bantuan software SPSS 15 for windows, hasil penelitian yang diperoleh akan menunjukan pengaruh yang diberikan variabel independen terhadap variabel dependen baik secara langsung maupun tidak langsung.

Pengujian hipotesis ditujukan untuk mengetahui pengaruh dimensi In Store Display yang meliputi Branding $\left(\mathrm{X}_{1}\right)$, Durability $\left(\mathrm{X}_{1.2}\right)$, Flexibility $\left(X_{1.3}\right)$, Modularity $\left(X_{1.4}\right)$, Visibility\&Accessibility $\left(X_{1.5}\right)$, Creatifity $\left(X_{1.6}\right)$, terhadap keputusan pembelian minuman berkarbonasi merek CocaCola (Y). Pengujian hipotesis tersebut dilakukan dengan menggunakan uji statistik path analysis.

Tabel 12 berikut ini menyajikan hasil perhitungan koefisien korelasi antara setiap dimensi (sub variabel) in store display dengan keputusan pembelian.

Tabel 12

Matrik Korelasi antara Dimensi In Store Display dengan Keputusan Pembelian

\begin{tabular}{|c|c|c|c|c|c|c|c|}
\hline & $\mathbf{Y}$ & $\mathbf{X}_{1.1}$ & $\mathbf{X}_{1.2}$ & $\mathbf{X}_{1.3}$ & $\mathbf{X}_{1.4}$ & $\mathbf{X}_{1.5}$ & $\mathbf{X}_{1.6}$ \\
\hline $\mathbf{Y}$ & 1,000 & 0,608 & 0,694 & 0,557 & 0,787 & 0,702 & 0,396 \\
\hline $\mathbf{X}_{1.1}$ & 0,608 & 1,000 & 0,689 & 0,399 & 0,420 & 0,194 & 0,126 \\
\hline $\mathbf{X}_{1.2}$ & 0,694 & 0,689 & 1,000 & 0,391 & 0,453 & 0,291 & 0,170 \\
\hline $\mathbf{X}_{1.3}$ & 0,557 & 0,399 & 0,391 & 1,000 & 0,425 & 0,346 & 0,307 \\
\hline $\mathbf{X}_{1.4}$ & 0,787 & 0,420 & 0,453 & 0,425 & 1,000 & 0,517 & 0,290 \\
\hline $\mathbf{X}_{1.5}$ & 0,702 & 0,194 & 0,291 & 0,346 & 0,517 & 1,000 & 0,228 \\
\hline $\mathbf{X}_{1.6}$ & 0,396 & 0,126 & 0,170 & 0,307 & 0,290 & 0,228 & 1,000 \\
\hline
\end{tabular}

Sumber: Hasil pengolahan Data 2008

Tabel 12 menunjukkan hubungan setiap sub variabel $X$ dari $X_{1}$ hingga $X_{6}$ dengan $Y$. Berdasarkan tabel diketahui nilai hubungan antara sub variabel $X$ dengan $Y$ yang terbesar adalah hubungan antara modularity sebagai $\left(X_{1.4}\right)$ dan keputusan pembelian sebagai $(Y)$ dengan nilai 0,787 . Hal tersebut menunjukkan bahwa terdapat hubungan yang signifikan antara modularity dengan keputusan pembelian. Sedangakan hubungan terbesar antara setiap variabel $X$ dimiliki oleh branding sebagai $X_{1.1}$ dengan durability sebagai $X_{1.2}$ sebesar 0,689 . Koefisien tersebut menunjukkan bahwa terdapat hubungan antara branding dan durability signifikan.

Dari hasil pengujian untuk uji $F$ melalui program SPSS 15.0 (Tabel Anova) diperoleh data pengujian pada tabel Anova menunjukan bahwa $F_{\text {hitung }}>F_{\text {tabel }}$ yaitu $140,637>2,710$ dengan tingkat signifikan (sig) sama dengan 0,000. atau lebih kecil dari 0,05 , sehingga dapat diambil kesimpulan bahwa Ho ditolak oleh karena itu pengujian secara individual dapat dilakukan.

Hasil pengujian koefisien jalur setiap variabel ditampilkan pada Tabel 13 di bawah ini.

Tabel 13

Hasil Pengujian Koefisien Jalur

\begin{tabular}{|c|c|c|c|c|}
\hline \multicolumn{2}{|c|}{ Koefisien Jalur } & $t_{\text {hitung }}$ & $t_{\text {tabel }}$ & Kesimpulan \\
\hline $\mathrm{PYX}_{1.1}$ & 0,159 & 3,396 & 1,988 & $\mathrm{H}_{\mathrm{o}}$ Ditolak \\
\hline$P Y X_{1.2}$ & 0,273 & 5,807 & 1,988 & $\mathrm{H}_{\mathrm{o}}$ Ditolak \\
\hline $\mathrm{PYX}_{1.3}$ & 0,079 & 2,031 & 1,988 & $\mathrm{H}_{0}$ Ditolak \\
\hline $\mathrm{PYX}_{1.4}$ & 0,341 & 7,940 & 1,988 & Ho Ditolak \\
\hline $\mathrm{PYX}_{1.5}$ & 0,359 & 9,188 & 1,988 & Ho Ditolak \\
\hline $\mathrm{PYX}_{1.6}$ & 0,125 & 3,561 & 1,988 & Ho Ditolak \\
\hline
\end{tabular}

Sumber : Hasil Pengolahan Data 2008

Berdasarkan Tabel di atas pengujian hipotesis dapat diketahui bahwa signifikansi setiap dimensi in store display masing-masing sebesar 0,001 , $0,000,0,045,0,000,0,000$ dan 0,001 lebih kecil dari 0,05 , hal tersebut berarti bahwa $\mathrm{H}_{0}$ ditolak. Selain berdasarkan koefisien korelasi, pengujian hipotesis dapat dilakukan dengan membandingkan nilai tabel dengan thitung untuk á $=0,05$, hasil pengolahan data menunjukkan bahwa thitung dari setiap dimensi in store display adalah 3,396, 5,807, 2,031, 7,940, 9,188 dan 3,561 lebih besar dari tabel yaitu 1,988 , dengan demikian $H_{0}$ ditolak. Hasil pengujian signifikansi koefisien korelasi serta uji-t menyatakan bahwa $\mathrm{H}_{0}$ ditolak. Artinya terdapat pengaruh yang positif dan signifikan antara in store display yang terdiri dari dimensi branding, durability, flexibility, modularity, visibility\& accessibility dan creatifity terhadap keputusan pembelian.

Pemaparan di atas sesuai dengan pendapat Shimp (2003:321) Para pemasar berupaya mempengaruhi keputusan pembelian dengan menggunakan beragan tampilan atau pajangan iklan (display).

Selain itu seperti yang diungkapkan oleh Uyung Sulaksana (2007:112) Display dapat mendorong Trial, dan memberi in store support bagi alat promosi lainnya. Iklan berfungsi memperkuat stimuli dalam toko, yaitu dengan mengingatkan konsumen pada merek itu ketika mereka melihatnya terpajang di rak. Display membuat iklan tersebut lebih efektif.

Kessler, Shimp, dalam Fandy Tjiptono, Gregorius Chandra dan Dedi Adriana (2008:569) di dalam toko setiap kategori produk meningkat 


\section{StrategiC}

drastis, hal ini menyiratkan bahwa semakin banyak konsumen yang belum memutuskan membeli, implikasinya bahwa komunikasi point of purchase display secara efektif memainkan peranan signifikan dalam mempengaruhi konsumen dan menaikkan penjualan.

Adapun hasil pengujian pengaruh in store display terhadap keputusan pembelian disajikan pada Tabel 14 di bawah ini.

Tabel 14

Hasil Pengujian Pengaruh Consumer Promotion Terhadap Respon Konsumen

\begin{tabular}{|l|c|c|c|c|}
\hline $\begin{array}{c}\text { Pengaruh } \\
\text { Variabel }\end{array}$ & $\begin{array}{c}\text { Koefisien } \\
\text { Jalur }\end{array}$ & $\begin{array}{c}\text { Pengaruh } \\
\text { Langsung }\end{array}$ & $\begin{array}{c}\mathbf{R}^{2} \mathbf{Y} \mathbf{X}_{1.1}, \\
\ldots, \mathbf{Y} \mathbf{X}_{1.6}\end{array}$ & $\begin{array}{c}\text { Pengujian } \\
\text { Hipotesis }\end{array}$ \\
\hline $\mathrm{X}_{1.1}$ terhadap $\mathrm{Y}$ & 0,159 & 0,0253 & 0,0966 & Ho ditolak \\
\hline $\mathrm{X}_{1.2}$ terhadap $\mathrm{Y}$ & 0,273 & 0,0745 & 0,1894 & Ho ditolak \\
\hline $\mathrm{X}_{1.3}$ terhadap $\mathrm{Y}$ & 0,079 & 0,0062 & 0,0440 & Ho ditolak \\
\hline $\mathrm{X}_{1.4}$ terhadap $\mathrm{Y}$ & 0,341 & 0,1163 & 0,2683 & Ho ditolak \\
\hline $\mathrm{X}_{1.5}$ terhadap $\mathrm{Y}$ & 0,359 & 0,1289 & 0,2518 & Ho ditolak \\
\hline $\mathrm{X}_{1.6}$ terhadap $\mathrm{Y}$ & 0,125 & 0,0156 & 0,0496 & Ho ditolak \\
\hline $\mathbf{R}^{\mathbf{2}}$ & & $\mathbf{0 , 8 9 9 6}$ & \\
\hline
\end{tabular}

Sumber : Hasil Pengolahan Data 2008

Berdasarkan hasil perhitungan di atas diketahui bahwa pengaruh in store display terhadap keputusan pembelian minuman berkarbonasi merek Coca-Cola adalah sebesar 0,8996 sedangkan koefisien variabel lain di luar variabel

$$
P_{Y \in}=\sqrt{1-R^{2} Y\left(x_{1.1}, x_{1.2}, x_{\cdot 1.3}, x_{1.4}, x_{1.5}, x_{1.6}\right)}
$$

$\mathrm{X}_{1.1}$ sampai $\mathrm{X}_{1.6}$ ditentukan dengan rumus:

$$
\begin{aligned}
& =\sqrt{1-0,8996} \\
& =0,317
\end{aligned}
$$

Hal tersebut berarti bahwa $X_{1.1}$ sampai $X_{1.6}$ secara bersama-sama mempengaruhi keputusan pembelian sebesar $89,96 \%$ dan sisanya sebesar $(0,317)^{2}=0,1004 \times 100 \%=10,04 \%$ dipengaruhi oleh faktor lain yang tidak termasuk dalam penelitian ini.

\section{IMPLIKASI HASIL PENELITIAN}

Berdasarkan hasil pengolahan data untuk variabel pengaruh in store display terhadap keputusan pembelian menghasilkan penolakan $\mathrm{Ho}$, artinya dapat dinyatakan bahwa terdapat pengaruh yang positif dan signifikan antara in store display terhadap keputusan pembelian, persentase ideal pengaruh in store display terhadap keputusan pembelian adalah $100 \%$, namun dalam penelitian ini persentase pengaruh in store display terhadap keputusan pembelian adalah sebesar 89,96\% karena sisanya sebesar $10,04 \%$ merupakan pengaruh dari faktor lain yang tidak termasuk dalam penelitian ini.

Berdasarkan hasil penelitian mengenai pengaruh in store display terhadap keputusan pembelian minuman berkarbonasi merek CocaCola di Carrefour Paris Van Java, maka dihasilkan temuan-temuan sebagai berikut:

1. Tampilan in store display merek Coca-Cola di Carrefour Paris Van Java berdasarkan data yang diperoleh dari 100 responden sudah termasuk kategori baik. Teori serta konsep dimensi dari in store display yang digunakan dalam penelitian ini mengadaptasi dan memodifikasi teori serta konsep yang berasal dari Fandy Tjiptono, Gregorius Chandra dan Dedi Adriana (2008:575), yaitu:

a. Branding, nama merek dan atau logo jelas terpangpang di rak pajangan (display).

b. Durability, umur ekonomis pajangan, kualitas bahan yang digunakan (misalnya, awet atau tahan lama, anti karat), kekuatan stabilitas pajangan (mampu menyangga produk yang dipajang; tidak mudah goyang atau jatuh).

c. Flexibility, dapat disesuaikan dengan lingkungan dan kondisi gerai pengecer (misalnya, dapat menyesuaikan bentuk ruang yang tersedia; mudah dipindah posisinya sesuai layout toko; rak-raknya bersifat 'knock-down').

d. Modularity, kemudahan dalam penggantian rak (bilamana dibutuhkan), rak-rak yang ada dapat disesuaikan dengan setiap produk dan atau kemasan baru.

e. Visibility\&accessibility, kebersihan unit pajangan, penataan kategori dan item produk, kemudahan bagi konsumen untuk menjangkau produk pada rak.

f. Creatifity, keunikan desain unit pajangan, dalam hal bentuk, penataan produk dan interaktifitas.

2. Tingkat keputusan pembelian minuman berkarbonasi merek Coca-Cola di Carrefour Paris Van Java berdasarkan data yang diperoleh dari 100 responden sudah termasuk kategori baik. Teori serta konsep yang di pakai dalam penelitian ini adalah menurut Menurut Kotler dan Amstrong (2006:129), bagi konsumen sebenarnya pembelian bukanlah hanya merupakan satu tindakan saja, melainkan terdiri dari beberapa tindakan yang 
meliputi keputusan tentang jenis produk, bentuk, merek, jumlah, dan penjual.

3. in store display mempunyai pengaruh yang signifikan terhadap keputusan pembelian, dimana pengaruh paling besar di dapat dari pengaruh dimensi modularity, hal ini dikarenakan dari perspektif pemasar suatu toko atau gerai dapat mempunyai sejumlah efek yang diharapkan pada konsumen. Salah satunya adalah membantu membentuk arah maupun durasi perhatian konsumen, sehingga meningkatkan kemungkinan pembelian untuk produk yang mungkin saja terabaikan suasana toko dapat pula mendatangkan reaksi emosi tertentu dari konsumen. Dalam perspektif lain bahwa modularity mempunyai fungsi untuk mengatur penempatan rak pajangan sehingga konsumen atau pengunjung yang datang ke Carrefour Paris Van Java akan melihat langsung bagaimana penataan display CocaCola dan dapat merasakan kenyamanan serta akhirnya melakukan pembeilan. Kemudian dengan adanya kesesuaian antara rak pajangan dengan produk yang dipajang menimbulkan kesan tersendiri bagi konsumen. Berdasarkan pemaparan di atas, ditemukan temuan teoritis yaitu berupa kaitan atau pengaruh antara modularity dengan keputusan pembelian.

Sutisna (2001:57): "Cara pemajangan produk di rak-rak toko akan sangat membantu dalam penjualan produk yang low involvement. Penempatan produk pada tempat yang tersembunyi dan tidak menarik akan sulit dilihat oleh konsumen. Produk yang dipajang pada tempat yang mudah dilihat oleh konsumen dengan tata letak yang menarik akan membantu meningkatkan penjualan. Keinginan untuk membeli timbul ketika melihat produk itu".

Kegiatan promosi melalui in store display cukup efektif, mengingat menurut penelitian pertumbuhan industri ritel di Indonesia semakin meningkat dan semakin banyak pula orang yang berkunjung ke Departemen Store baik untuk melakukan pembelian atau pun hanya sekedar liburan. Secara teoritis menurut Wiliam J.Scultz, Display consist of stimulating customers's attention and interest in a product or a store, and desire to buy the product or patronize the store, through direct visual appeal' (Buchari Alma, 2005:142). (Display adalah mengenai bagaimana menarik perhatian konsumen akan sebuah produk atau toko, dan membengkitkan keinginan konsumen untuk membeli produk melalui penampilan produk secara langsung).

Pendapat ahli di atas, menjelaskan bahwa ketika konsumen masuk ke toko dan melihat langsung produk yang dipajang pada display dengan penempatan dan desain yang menarik akan menimbulkan minat beli konsumen. Seperti yang dikemukakan oleh Sutisna (2002:163) bahwa: "... ketika konsumen mengunjungi sebuah toko tata letak rak pajangan di dalam toko akan mempengaruhi perilaku pengunjung".

\section{SIMPULAN DAN SARAN}

\section{Simpulan}

Berdasarkan hasil penelitian, dapat diambil simpulan sebagai berikut:

1. Tanggapan responden terhadap pelaksanaan in store display secara umum sudah baik, persepsi responden terhadap in store display pada dimensi branding ditinjau dari (brand recodnition pada konsumen) kemudahan mengenali merek Coca-Cola pada rak pajangan (display), merupakan dimensi yang paling tinggi mendapatkan skor, hal ini dikarenakan display Coca-Cola di outlet modern lebih banyak dijumpai sehingga konsumen lebih mudah mengenali merek Coca-Cola dibandingkan merek pesaingnya. Sedangkan perolehan hasil skor paling rendah masih pada dimensi modularity ditinjau dari segi kesesuaian rak pajangan dengan merek Coca-Cola yang baru, hal ini dikarenakan rak pajangan (display) Coca-Cola masih menggunakan display yang lama sehingga konsumen kurang mengetahui apabila ada merek Coca-Cola yang baru.

2. Tenggapan responden terhadap keputusan pembelian yang terdiri dari pemilihan produk, pemilihan merek, pemilihan saluran pembelian, waktu pembelian, dan jumlah pembelian. secara umum sudah baik. Persepsi responden terhadap keputusan pembelian pada dimensi pemilihan berdasarkan merek ditinjau dari kepercayaan terhadap merek, merupakan dimensi yang memperoleh skor yang paling tinggi. Hal ini menunjukkan bahwa mayoritas 
responden memilih minuman berkarbonasi merek Coca-Cola karena kualitasnya yang baik dibandingkan dengan merek minuman berkarbonasi lainnya. Sedangkan persepsi responden terhadap keputusan pembelian dimensi pemilihan berdasarkan waktu pembelian ditinjau dari ketidakteraturan pembelian mendapatkan skor yang paling rendah dari dimensi-dimensi lainnya, hal ini dikarenakan responden mengkonsumsi minuman berkarbonasi merek Coca-Cola tidak hanya pada saat membutuhkan.

3. In store display berpengaruh secara positif terhadap keputusan pembelian. Sehingga setiap kegiatan promosi yang dibentuk dengan perencanaan yang baik dalam pelaksanaan in store display akan mempengaruhi keputusan pembelian.

\section{Saran}

Berdasarkan hasil penelitian, maka penulis memberikan saran mengenai in store display dalam kaitannya untuk meningkatkan keputusan pembelian, yaitu:

1. In store display merupakan kegiatan promosi dalam bentuk media pajangan yang dilakukan di dalam outlet modern maupun outlet tradisional, tujuannya yaitu membantu mengarahkan perhatian konsumen terhadap produk atau merek dan menciptakan keputusan pembelian. Berdasarkan penelitian bahwa pada dimensi modularity ditinjau dari segi kesesuaian rak pajangan (display) dengan merek Coca-Cola yang baru memperoleh skor paling rendah, sebagai solusinya diharapkan The Coca-Cola Company dalam hal ini CocaCola Indonesia $(\mathrm{CCl})$ sebagai produsen minuman berkarbonasi merek Coca-Cola senantiasa melakukan perbaikan-perbaikan dalam hal apabila memasarkan merek CocaCola dengan varian baru, maka harus diikuti dengan perubahan pada rak pajangan (display) untuk menjaga kesesuaian antara rak pajangan dengan varian Coca-Cola yang baru, agar konsumen dapat melihat perubahan tersebut dan menimbulkan daya tarik bagi konsumen untuk melakukan pembelian.

2. Mengenai keputusan pembelian minuman berkarbonasi merek Coca-Cola dari lima dimensi keputusan pembelian, skor terkecil diperoleh dari dimensi pemilihan berdasarkan waktu pembelian ditinjau dari ketidakteraturan waktu pembelian, artinya bahwa The CocaCola Company sebagai produsen minuman berkarbonasi merek Coca-Cola harus tetap menjaga konsistensi di mana konsumen saat ini mengkonsumsi merek Coca-Cola tidak hanya pada saat membutuhkan, jadi setiap waktu konsumen dapa membeli minuman berkarbonasi merek Coca-Cola.

3. Hasil penelitian menyatakan bahwa in store display berpengaruh secara positif terhadap keputusan pembelian, maka penulis merekomendasikan agar perusahaan harus tetap menjaga dan meningkatkan kualitas display yang saat ini telah dilakukan dengan cara melakukan perubahan-perubahan pada rak pajangan (display) sehingga konsumen tertarik untuk melakukan pembelian.

\section{DAFTAR PUSTAKA}

Basu Swastha. 2002. Azas-Azas Marketing. Jakarta: Liberty.

Buchari Alma. 2004. Manajemen Pemasaran dan Pemasaran Jasa. Bandung: CV. Alfabeta.

Cummins, Julian dan Roddy Mullin. 2004. Sales Promotions. Jakarta: PPM.

Fandy Tjiptono, Gregorius Chandra, dan Dedi Adriana. 2008. Pemasaran Strategik, Yogyakarta.

Fandy Tjiptono. 2002. Strategi Pemasaran. Yogyakarta: PT. ANDI Offset.

Fandy Tjiptono. Anastasia Diana. 2003. Total Quality Management. Yogyakarta: ANDI.

Griffin, Ricky W. and Ronald J. Ebert. 2006. Business 8th Edition. New Jersey: Pearson International Edition. Prentice Hall.

Harun Al Rasyid. 1994. Teknik Penarikan Sampel dan Penyusunan Skala. Bandung: UNPAD.

Husein, Umar. 2001. Riset Perilaku Konsumen. Jakarta: Gramedia Pustaka Utama.

Jefkins, Frank. 1995. Periklanan. Jakarta: Erlangga.

Jefkins, Frank. 1997. Periklanan. Edisi Ketiga. Jakarta: Erlangga.

Kotler, Philip dan Amstrong, Gary. 2006. Principles of Marketing. New Jersey: Prentice Hall.

Kotler, Philip. 2005. Manajemen Pemasaran, Analisis, Perencanaan dan Implementasi dan Kontrol. Jilid 1 dan 2. Jakarta: Indeks Kelompok Gramedia. 
Schiffman, Leon.G. dan Kanuk, Leslie. 2003. Consumer Behavior. Prentice Hall Internasionallnc.

Shimp, Terence. A. 2003. Periklanan Promosi: Aspek Tambahan Komunikasi Pemasaran

Sugiyono. 2005. Metode Penelitian Bisnis. CV. Alfabeta.

Suharsimi Arikunto. 2006. Prosedur Penelitian Suatu Pendekatan Praktek. Jakarta: PT. Rineka Cipta.

Sutisna. 2004. Perilaku Konsumen dan Komunikasi Pemasaran. Bandung: PT. Remaja Rosda Karya.

Uyung Sulaksana. 2007. Integrated Marketing Communications. Yogyakarta: Pustaka Pelajar.

\section{Majalah}

Marketing 15/XXII/27 Juli-9 Agustus 2006; 08/VII/Agustus 2007; 01/VII/Januari 2008; 